\title{
Impact of model resolution on simulated wind, drifting snow and surface mass balance in Terre Adélie, East Antarctica
}

\author{
Jan T.M. LENAERTS, ${ }^{1}$ Michiel R. VAN DEN BROEKE, ${ }^{1}$ Claudio SCARCHILLI, ${ }^{2}$ \\ Cécile AGOSTA ${ }^{3}$ \\ ${ }^{1}$ Institute for Marine and Atmospheric Research, Utrecht University, Utrecht, The Netherlands \\ E-mail: j.lenaerts@uu.nl \\ ${ }^{2}$ ENEA, Rome, Italy \\ ${ }^{3}$ Laboratoire de Glaciologie et Géophysique de l'Environnement, Grenoble, France
}

\begin{abstract}
This paper presents the impact of model resolution on the simulated wind speed, drifting snow climate and surface mass balance (SMB) of Terre Adélie and its surroundings, East Antarctica. We compare regional climate model simulations at 27 and $5.5 \mathrm{~km}$ resolution for the year 2009 . The wind speed maxima in Terre Adélie and the narrow glacial valleys of Victoria Land are better represented at $5.5 \mathrm{~km}$ resolution, because the topography is better resolved. Drifting snow sublimation is $>100 \mathrm{~mm} \mathrm{a}^{-1}$ in regions with high wind speeds. Our results indicate a strong feedback between topography, wind gradients and drifting snow erosion. As a result, SMB shows much more local spatial variability at $5.5 \mathrm{~km}$ resolution that is controlled by drifting snow erosion, whereas the large-scale SMB gradient is largely determined by precipitation. Drifting snow processes lead to ablation in the narrow glacial valleys of Victoria Land. The integrated SMB equals $86 \mathrm{Gt}$. Although wind climate, drifting snow processes and SMB variability are better represented at $5.5 \mathrm{~km}$, the area-integrated SMB is not significantly different between the simulations at 27 and $5.5 \mathrm{~km}$. A horizontal resolution of $27 \mathrm{~km}$ is sufficient to realistically simulate ice-sheet wide SMB.
\end{abstract}

\section{INTRODUCTION}

East Antarctica is characterized by a long winter (>10 months) with extremely low temperatures and strong winds. Due to temperature inversion near the surface and the sloping topography of the ice sheet, intense and directionally constant katabatic winds develop, which are accelerated in regions with confluent topography (Parish and Bromwich, 1987). Due to its extreme climate, with probably the strongest near-surface winds on Earth, Terre Adélie (Fig. 1) and its surroundings is an interesting topic for scientific studies. Conversely, these extreme conditions make it hard to perform in situ measurements. Wendler and others (1997) described 4 months of wind speed measurements (until the instruments broke during a storm) in coastal Terre Adélie (Cape Denison). These data confirm that the highest annual mean wind speed $\left(19.1 \mathrm{~m} \mathrm{~s}^{-1}\right)$, measured by Mawson (1915) and corrected by Loewe (1972), occurs here. Wendler and others (1997) also found that the spatial variability is large on scales of tens of kilometers, owing to rough topography with alternating valleys and ridges: for instance, the annual mean wind speed at the French station Dumont d'Urville (situated $120 \mathrm{~km}$ west of Cape Denison on a small island $2 \mathrm{~km}$ offshore) is only $9.5 \mathrm{~m} \mathrm{~s}^{-1}$.

Topography in Antarctica strongly controls not only the wind climate, but also the spatial variability of snow accumulation, sublimation and erosion, which are all components of the surface mass balance (SMB). Most importantly, SMB strongly decreases from the coast to the Antarctic plateau, but it also varies on much smaller scales (Van de Berg and others, 2006; Agosta and others, 2012; Lenaerts and others, 2012a). The SMB at a specific location (units $\mathrm{mm}$ w.e. $\mathrm{a}^{-1}$ or $\mathrm{kg} \mathrm{m}^{-2} \mathrm{a}^{-1}$ ) is defined as

$$
\mathrm{SMB}=\int_{1 \text { year }}\left(P-\mathrm{SU}_{\mathrm{s}}-\mathrm{RU}-\mathrm{ER}_{\mathrm{ds}}-\mathrm{SU}_{\mathrm{ds}}\right) \mathrm{d} t
$$

where $P$ is precipitation (snow and rain), $\mathrm{SU}_{\mathrm{s}}$ is surface sublimation, $\mathrm{RU}$ is runoff from rainfall, snow and ice melt, and $E R_{\mathrm{ds}}$ and $S \mathrm{SU}_{\mathrm{ds}}$ represent drifting snow erosion and sublimation, respectively. Due to low temperatures, significant rainfall and runoff do not occur in East Antarctica and $\mathrm{SU}_{\mathrm{s}}$ is small. Snowfall is generally low; as a result, most of the East Antarctic plateau has an annual SMB $<50 \mathrm{~mm}$ w.e. $\mathrm{a}^{-1}$ (Lenaerts and others, 2012a), increasing to typically 200$500 \mathrm{~mm}$ w.e. $\mathrm{a}^{-1}$ in the coastal regions. Because of the dry climate, drifting snow sublimation, $\mathrm{SU}_{\mathrm{ds}}$, and erosion, $\mathrm{ER}_{\mathrm{ds}}$, may remove a significant part of the accumulated snow (Frezzotti and others, 2004), and may even lead to ablation $(\mathrm{SMB}<0)$ in the driest and windiest regions (Bintanja, 1999; Van den Broeke and others, 2006; Genthon and others, 2007; Lenaerts and Van den Broeke, 2012). Remotely sensed observations show that drifting snow events occur frequently in East Antarctica (Mahesh and others, 2003), evidenced by the presence of large-scale snow 'billows' and dunes after these events (Scarchilli and others, 2010). Moreover, during strong events, drifting snow layers may become as deep as, or deeper than, $200 \mathrm{~m}$ (Palm and others, 2011). Therefore, it is essential to include drifting snow physics when we simulate the East Antarctic climate and SMB (Frezzotti and others, 2002, 2007; Gallée and others, 2005; Scarchilli and others, 2010; Agosta and others, 2012).

Because of the impact of topography, many atmospheric processes occur on scales smaller than the typical horizontal resolution of atmospheric or climate models. In Antarctica, the spatial variability of precipitation is largely determined by topography (Bromwich, 1988), because of the dominant contribution of orographic precipitation. This enhances precipitation on the windward side of topographic features. Topography is smoothed as grid size increases, and as a result, SMB becomes a function of a model's horizontal resolution (Genthon and others, 2009). The slope in 
topography also determines the strength of the katabatic wind and resulting drifting snow. Snowdrift erosion, ER $\mathrm{ds}$, represents the horizontal divergence of the wind transport of snow (Lenaerts and others, 2012b) and strongly depends on spatial variations in wind speed. Lenaerts and Van den Broeke (2012) demonstrated that, at a horizontal resolution of $27 \mathrm{~km}, \mathrm{ER}_{\mathrm{ds}}$ is only significant $\left(>10 \mathrm{~mm}\right.$ w.e. $\left.\mathrm{a}^{-1}\right)$ on a regional scale, but we expect its importance to become more pronounced at higher resolution. An example is the presence of so-called megadunes, typical of interior East Antarctica. Megadunes have a typical wavelength of 5$10 \mathrm{~km}$ and their development is presumably related to smallscale variations in wind speed (Fahnestock and others, 2000; Frezzotti and others, 2002). In this paper, we discuss the impact of horizontal resolution on the representation of the wind climate and SMB of eastern East Antarctica (135$\left.180^{\circ} \mathrm{E}\right)$, including Terre Adélie, Victoria Land and most of Wilkes Land. We run the regional atmospheric climate model RACMO2.1/ANT for 1 year (2009) at high horizontal resolution $(5.5 \mathrm{~km})$. We compare the wind climate, drifting snow climate and SMB with the output of the previous run with the same model version at $27 \mathrm{~km}$ (Lenaerts and others, 2012b), and evaluate the differences using available observations.

\section{METHODS}

\section{Numerical set-up}

For the purpose of this study we use the Regional Atmospheric Climate MOdel version 2.1 (RACMO2.1/ANT). RACMO2.1/ANT combines the dynamical processes of the High Resolution Limited Area Model (HIRLAM; Undén and others, 2002) with the physical parameterizations from the European Centre for Medium-Range Weather Forecasts (ECMWF) model Cycle 23r1 (White, 2001). The latest version contains a multilayer snow model (Ettema and others, 2009) and a snow albedo scheme based on snow grain size (Kuipers Munneke and others, 2011). Additionally, a drifting snow routine is included in RACMO2.1/ANT, which is based on the bulk drifting snow routine of Déry and Yau (1999). The routine uses wind speed, temperature and specific humidity at the lowest model level $(\sim 7 \mathrm{~m})$ to calculate drifting snow sublimation, $\mathrm{SU}_{\mathrm{ds}}$, and transport, $\mathrm{TR}_{\mathrm{ds}}$. Assuming it is the only source of latent heat during drifting snow, the effect of $\mathrm{SU}_{\mathrm{ds}}$ on the near-surface atmosphere is explicitly included in RACMO2.1/ANT. Moreover, both $\mathrm{SU}_{\mathrm{ds}}$ and $\mathrm{ER}_{\mathrm{ds}}$ are included as explicit terms in the SMB scheme of RACMO2.1/ANT (Eqn (1)). By removing or depositing mass from the top snow layer, both processes can impact its density, which, in turn, limits the potential for drifting snow (Lenaerts and others, $2012 b)$. Lenaerts and others (2012b) provide additional details of the numerical set-up and a detailed evaluation of the near-surface climate and drifting snow characteristics. Among other things, they show that the model, with a horizontal resolution of $27 \mathrm{~km}$, is able to realistically simulate the near-surface climate (Lenaerts and Van den Broeke, 2012) and SMB (Lenaerts and others, 2012a) of the Antarctic ice sheet, without the need for post-calibration.

Here we further increase the horizontal resolution of RACMO2.1/ANT, from $27 \mathrm{~km}$ (RACMO/27 hereafter) to $5.5 \mathrm{~km}$ (RACMO/5.5 hereafter), to better resolve the complex topography of East Antarctica and related interactions with the atmosphere. The model domain encompasses the eastern part of East Antarctica (Fig. 1). The lateral boundaries

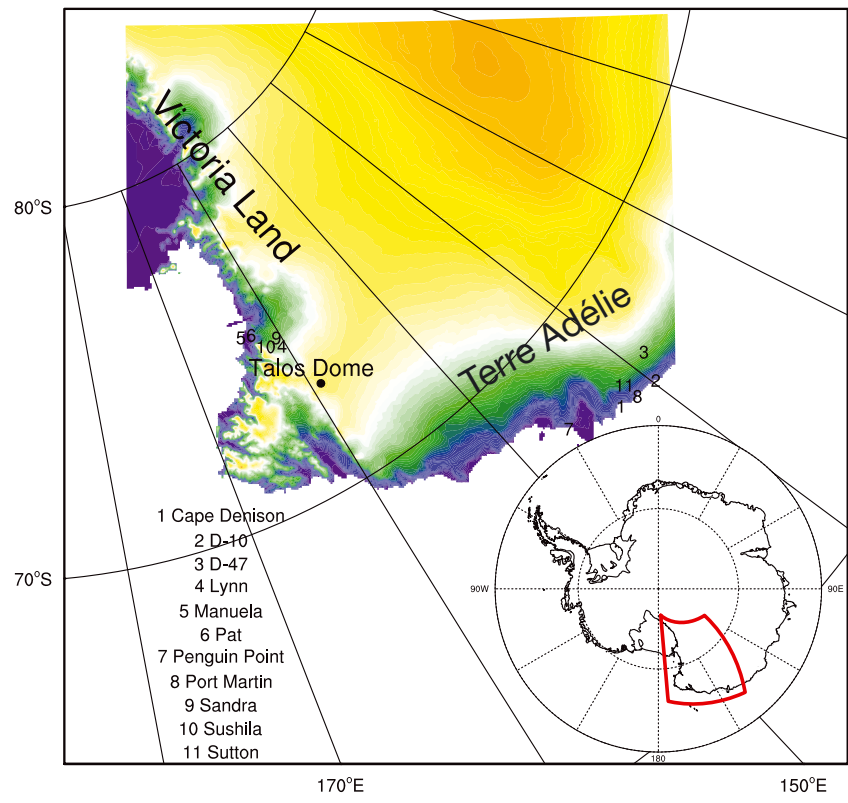

Fig. 1. Overview of model domain. Model topography is shown in colors, with scale ranging from 0 to $4000 \mathrm{~m}$ a.s.l. The position of the model domain on the Antarctic ice sheet is indicated in the inset. The locations and names of the AWSs used for wind speed evaluation (Nos. 1 to 11 , Fig. 3) are also given, together with the location of Talos Dome (Fig. 5).

are chosen to minimize crossing distinct topography. The atmospheric fields at these boundaries are provided by RACMO2.1/ANT at $27 \mathrm{~km}$ resolution, such that the effect of downscaling the atmospheric fields at the lateral boundaries remains small. Sea-ice extent and sea surface temperature are prescribed from ERA Interim reanalysis data (Dee and others, 2011). Because of the exploratory nature of this work and the high computational cost, we ran the model for a single year (2009). The snowpack is initialized with data from 1 January 2009 from RACMO/27. Model elevation in RACMO2.1/ANT is constant, which is a reasonable assumption considering the temporal scale ( 1 year) of this study.

\section{Observational data}

The near-surface climate of East Antarctica is monitored by different automatic weather stations (AWSs), which sample wind speed and direction at 3 or $10 \mathrm{~m}$ above the surface at hourly or sub-hourly resolution. Here we evaluate the model results for the AWSs located in rough topography and with high wind speeds $\left(>9 \mathrm{~m} \mathrm{~s}^{-1}\right)$. Figure 1 shows the locations and names of these stations. All wind-speed data are converted to a standard height of $10 \mathrm{~m}$ (Sanz Rodrigo, 2011).

At daily resolution, the modeled wind speed is compared with observational data (see Fig. 2 for locations) from AWSs at Larsen Glacier (a; $75^{\circ} \mathrm{S}, 161^{\circ} \mathrm{E}, 1350 \mathrm{~m}$ a.s.l.), Sitry (b; $72^{\circ} \mathrm{S}, 149^{\circ} \mathrm{E}, 2094 \mathrm{~m}$ a.s.I.), Priestley Glacier (c; $74^{\circ} \mathrm{S}$, $162^{\circ} \mathrm{E}, 1923 \mathrm{~m}$ a.s.I.) and David Glacier (d; $76^{\circ} \mathrm{S}, 159^{\circ} \mathrm{E}$, $1552 \mathrm{~m}$ a.s.l.), obtained from the Meteo Climatological Observatory of PNRA (Programma Nazionale di Ricerche in Antartide; http://www.climantartide.it). The first two stations are situated in the convergence slope/coastal areas of northern Victoria Land, whereas the latter two are located on the East Antarctic plateau (Fig. 1). 

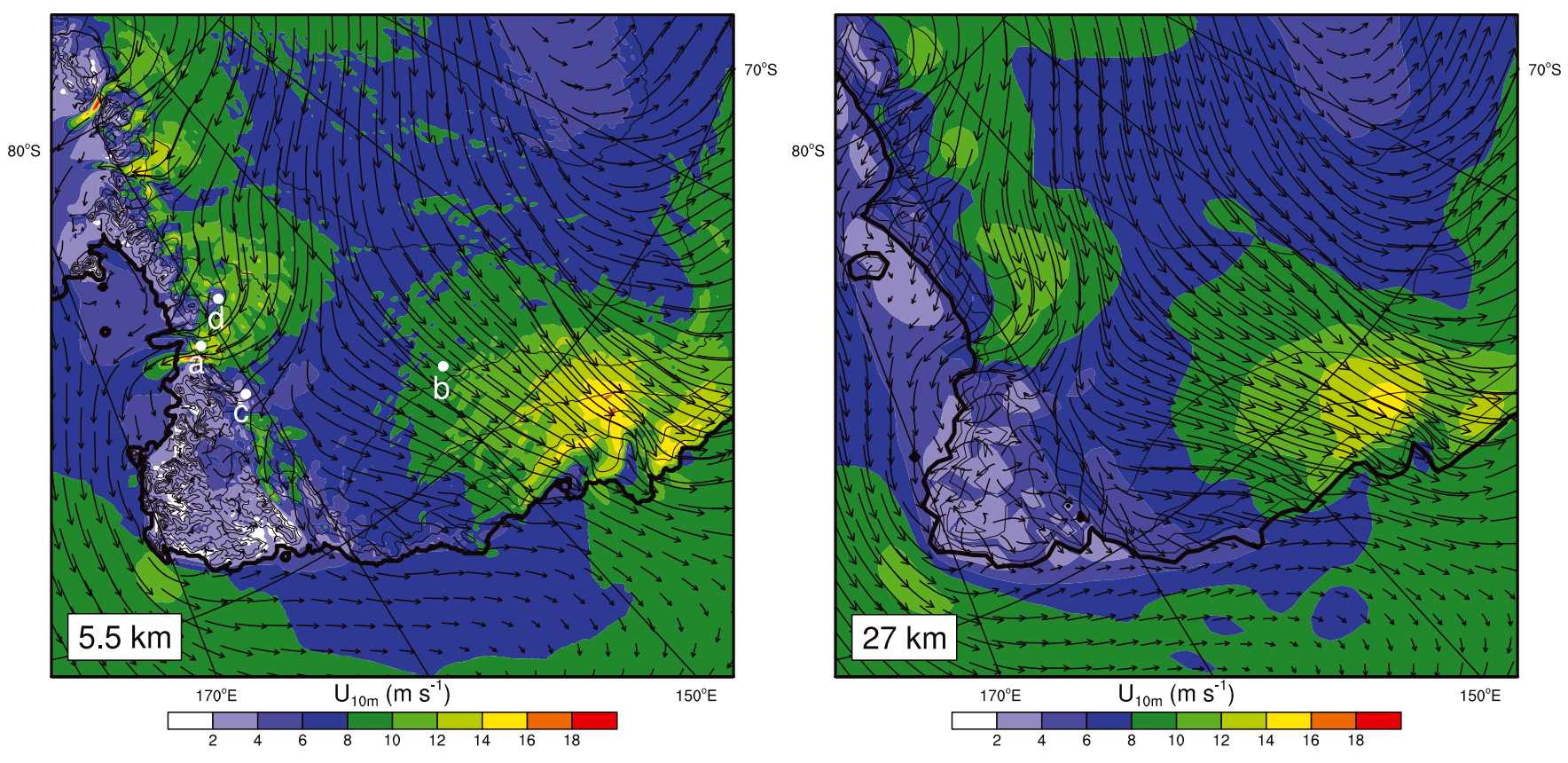

Fig. 2. Modeled annual mean (2009) $10 \mathrm{~m}$ wind speed (contours) and direction (arrows) in RACMO/5.5 (left) and RACMO/27 (right). The locations of the four AWSs in Figure $4 \mathrm{a}-\mathrm{d}$ are indicated by their respective letters.

Drifting snow measurements are sampled at the Talos Dome TALDICE drilling site $\left(72^{\circ} \mathrm{S}, 159^{\circ} \mathrm{E}, 2315 \mathrm{~m}\right.$ a.s.I.; http://www.taldice.org; see Fig. 1 for location). Measurements are obtained with FlowCapt ${ }^{\mathrm{TM}}$ driftometer sensors produced by ISAW Outdoor Environmental Monitoring (Chritin and others, 1999). The instrument is composed of four sensors: two of these are placed $0.2 \mathrm{~m}$ above the snow surface, and the other two $1 \mathrm{~m}$ above the surface. These instruments provide inaccurate estimates of the snow transport fluxes (Cierco and others, 2007), but do provide a realistic estimate of the occurrence of drifting snow.

Modeled SMB is compared with observations described by Agosta and others (2012). The observations originate from a $\sim 150 \mathrm{~km}$ long stake line that runs from the coast of Terre Adélie to the southwest (0-1800 ma.s.l.). Comparing RACMO to these observations can be regarded as a stringent test for model performance, because the stake line covers the strong SMB gradient between the relatively mild and windy coastal climate and drier and calmer conditions inland at high spatial resolution (100 data points).

\section{RESULTS}

\section{Wind climate}

Figure 2 compares annual mean $10 \mathrm{~m}$ wind speed of $\mathrm{RACMO} / 27$ with RACMO/5.5. Although RACMO/5.5 obviously shows much more detail, the regional patterns are similar. We find four areas of strong $\left(>14 \mathrm{~m} \mathrm{~s}^{-1}\right)$ winds: three over outlet glaciers (Byrd, Mulock and Reeves/David Glaciers) in the Transantarctic Mountains, with several jets above $10 \mathrm{~ms}^{-1}$, and one in coastal Terre Adélie, with a maximum wind speed of $16 \mathrm{~ms}^{-1}$ at $\sim 69^{\circ} \mathrm{S}, 143^{\circ} \mathrm{E}$, $1100 \mathrm{~m}$ a.s.I. On the smaller scale, the RACMO/5.5 wind field shows distinct features. Maximum wind speeds are higher and occur closer to the grounding line. Relatively narrow $(<20 \mathrm{~km})$ glacial valleys, in which the katabatic wind speeds converge and accelerate, are much better resolved at
$5.5 \mathrm{~km}$. In our simulation the strongest winds are found in the glacial valley of Reeves Glacier, with a maximum wind speed of $20.5 \mathrm{~m} \mathrm{~s}^{-1}$, and, to a lesser extent, David Glacier near the Italian base (Mario Zuchelli) in Terra Nova Bay $\left(\sim 75^{\circ} \mathrm{S}\right.$, $\left.163^{\circ} \mathrm{E}\right)$, and Byrd Glacier $\left(81^{\circ} \mathrm{S}, 158^{\circ} \mathrm{E}\right)$. The occurrence of these maxima is supported by results of Bromwich and others (1990), who showed that Reeves Glacier is the primary route for katabatic winds, and David Glacier is an important secondary outflow valley.

Lenaerts and others (2012b) showed that RACMO/27 underestimates high wind speeds in regions with complex topography. Figure 3 illustrates that in these regions, wind speeds in RACMO/5.5 agree better with observations. The root-mean-square error (rmse) decreases from $5.7 \mathrm{~m} \mathrm{~s}^{-1}$ to $3.6 \mathrm{~m} \mathrm{~s}^{-1}$, and the mean bias between model and observations drops from $-4.3 \mathrm{~m} \mathrm{~s}^{-1}$ to $-1.4 \mathrm{~m} \mathrm{~s}^{-1}$. Nonetheless, the extreme wind speeds $\left(>15 \mathrm{~m} \mathrm{~s}^{-1}\right)$ in Terre Adélie remain underestimated.

Figure 3 only shows long-term mean near-surface wind speeds. Drifting snow processes, however, are usually connected to short-lived wind speed maxima. To evaluate the model results at higher temporal resolution, Figure 4 shows the daily mean $10 \mathrm{~m}$ wind speed from RACMO/5.5, RACMO/27 and from available AWS observations. Due to limited temporal coverage and large gaps in the data, these AWSs are not included in Figure 3. At daily resolution, $\mathrm{RACMO} / 5.5$ shows clearly higher maximal wind speeds than RACMO/27 at all stations, except for Sitry (Fig. 3b), where topography is smooth and the model agrees very well with the observations, even at $27 \mathrm{~km}$ resolution. The other three stations are known to be major confluence areas, where the katabatic wind accelerates due to the convex shape of the glacier valley (Bromwich and others, 2000). At Larsen Glacier, the modeled timing and frequency of wind speed maxima agree very well with the observations, whereas at Priestley and David Glaciers, observed wind speed maxima remain largely underestimated, also by RACMO/5.5. The intense local katabatic flow at these locations is likely driven 


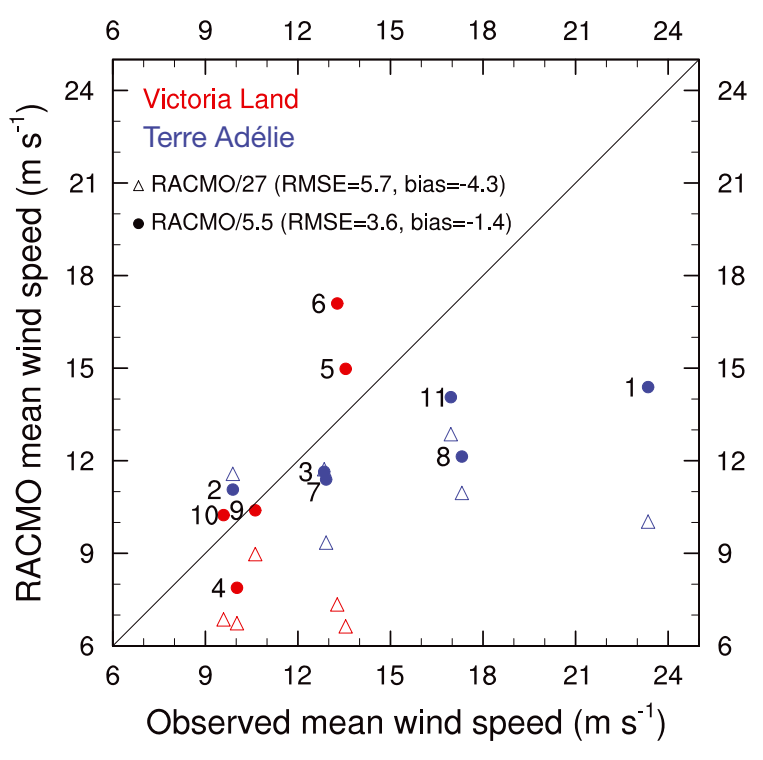

Fig. 3. Modeled mean (2009) vs observed (mean of instrumental record; Sanz Rodrigo, 2011) $10 \mathrm{~m}$ wind speed for RACMO/5.5 (dots) and RACMO/27 (triangles), located in Victoria Land (red) and Terre Adélie (blue). The RACMO wind speeds are weighted averages of the four gridpoints surrounding the location of the AWS. Only AWSs with mean observed $10 \mathrm{~m}$ wind speed $>9 \mathrm{~m} \mathrm{~s}^{-1}$ are shown. Their locations and names are given in Figure 1.

by topographic features at scales smaller than the model resolution of $5.5 \mathrm{~km}$, as also reported by Scarchilli and others (2010).

\section{Drifting snow}

Figure 5 presents a comparison of observed and modeled occurrence of drifting snow at Talos Dome during winter

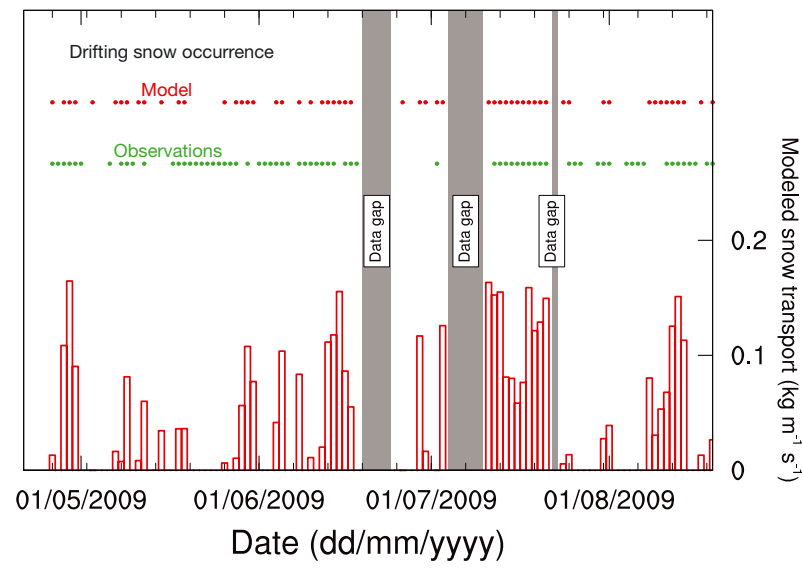

Fig. 5. Modeled and observed drifting snow occurrence (markers) at Talos Dome during the period May-August 2009, and modeled horizontal snow transport, $\mathrm{TR}_{\mathrm{ds}}$, during that period (red bars). The location of Talos Dome is shown in Figure 1.

2009. This site is characterized by a cold, windy climate: the modeled mean air temperature is $229 \mathrm{~K}$ and the average nearsurface wind speed is $8.5 \mathrm{~m} \mathrm{~s}^{-1}$ during the period shown in Figure 5 (May-August 2009). Figure 5 shows that drifting snow occurs frequently at Talos Dome. The model simulates a drifting snow frequency of $58 \%$, whereas the observations indicate that on $67 \%$ of the days drifting snow occurs. The model agrees with the observations on the timing and duration of especially the strongest drifting snow events, whereas some weaker events are not picked up, or their duration is underestimated (e.g. the long event at the end of May is not modeled). In total, $59 \%$ of the observed events are also modeled, whereas $30 \%$ of the modeled events are false detections. Unfortunately, no reliable drifting snow transport
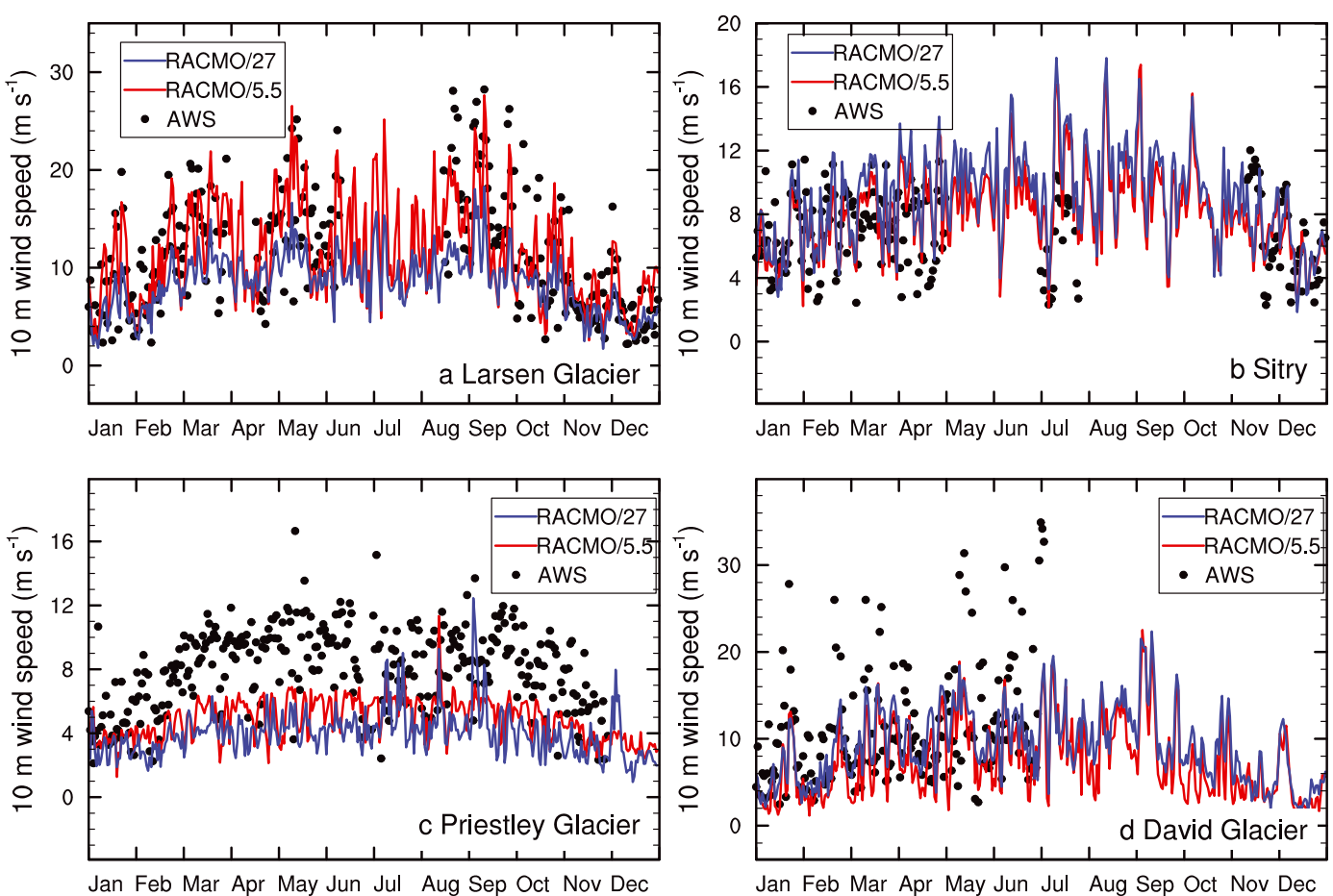

Fig. 4. Modeled daily mean (2009) vs observed (black dots) $10 \mathrm{~m}$ wind speed for RACMO/5.5 (red) and RACMO/27 (blue). The RACMO wind speeds are weighted averages of the four gridpoints surrounding the location of the AWS. The AWS locations are shown in Figure 2. Note that there are significant gaps in the observational data for all stations. 

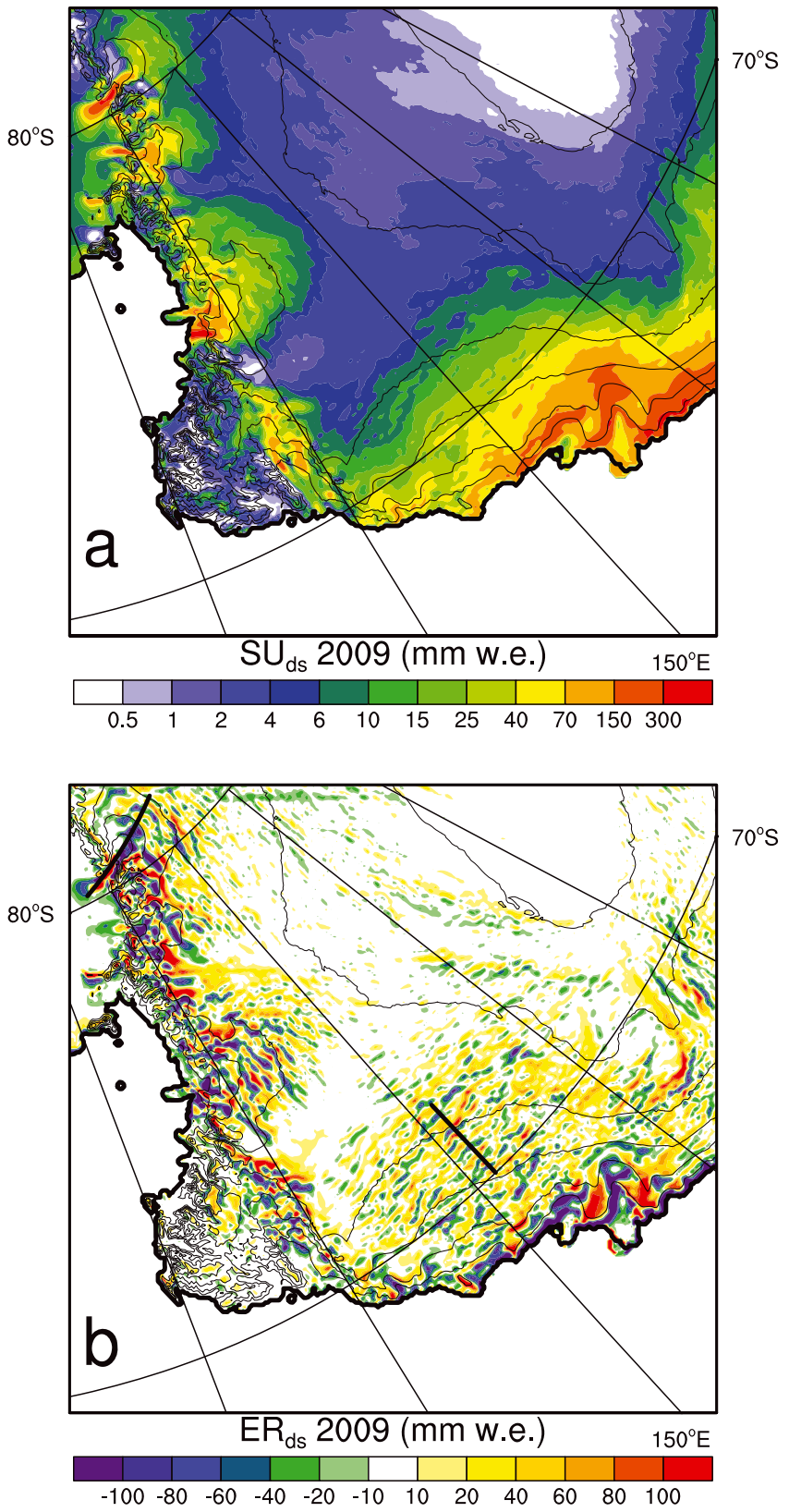

Fig. 6. Total (a) $S U_{\mathrm{ds}}$ and (b) $E R_{\mathrm{ds}}$ in 2009 as modeled by $\mathrm{RACMO} / 5.5$. The location transect shown in Figure 7 is shown by the thick black line.

observations are available for comparison. This illustrates the need for more detailed in situ observations of drifting snow.

Lenaerts and Van den Broeke (2012) discussed the drifting snow climate of Antarctica as simulated in RACMO/27. They found $\mathrm{SU}_{\mathrm{ds}}$ values up to $150 \mathrm{~mm}$ w.e. $\mathrm{a}^{-1}$ in coastal areas of East Antarctica. Because of the underestimation of the highest wind speeds in RACMO/27 (Fig. 3), a problem that is greatly reduced at higher horizontal resolution (Fig. 3), higher $\mathrm{SU}_{\mathrm{ds}}$ (Fig. 6a) and transport (not shown) are simulated in RACMO/5.5. $\mathrm{SU}_{\mathrm{ds}}$ exceeds $70 \mathrm{~mm}$ w.e. $\mathrm{a}^{-1}$ in large parts of coastal Terre Adélie, with peak values $>300 \mathrm{~mm}$ w.e. $\mathrm{a}^{-1}$. Similar values are found in the glacial valleys in Victoria Land where katabatic outflow is strongest (Fig. 2).

Drifting snow erosion, $\mathrm{ER}_{\mathrm{ds}}$, represents the divergence of horizontal snow transport, $\mathrm{TR}_{\mathrm{ds}}$. From a modeling perspective, this implies that $E R_{d s}$ is largely determined by how well the topography is resolved, i.e. by the horizontal
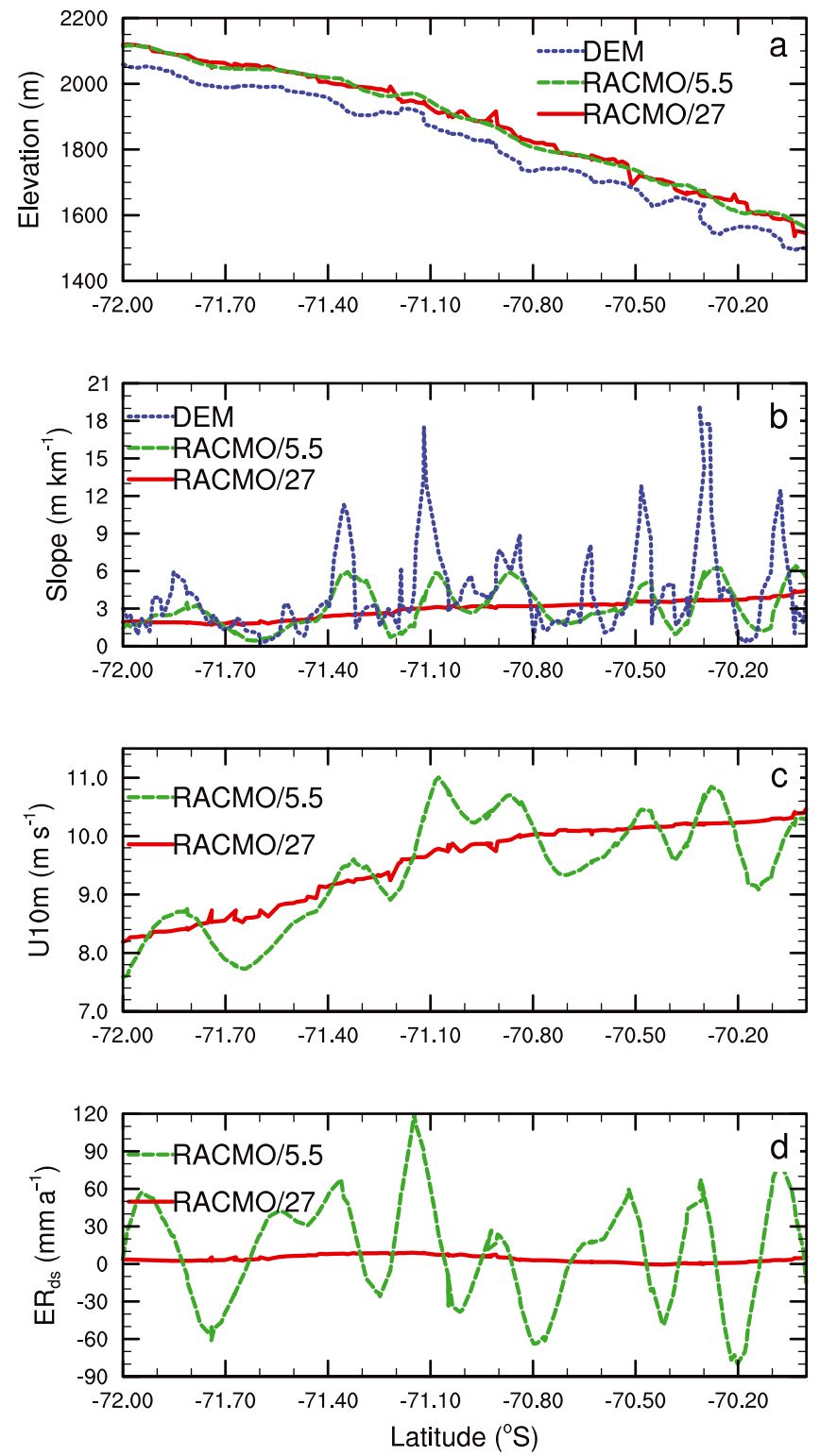

Fig. 7. Horizontal cross section through Terre Adélie (see Fig. 6 for location) of (a) surface elevation, (b) total surface slope in the $1 \mathrm{~km}$ DEM (Bamber and others, 2009), RACMO/5.5 and RACMO/27, (c) $10 \mathrm{~m}$ wind speed and (d) $\mathrm{ER}_{\mathrm{ds}}$ in 2009 from RACMO/5.5 and $\mathrm{RACMO} / 27$.

grid size. Figure $6 \mathrm{~b}$ presents $E R_{\mathrm{ds}}$ for 2009. On the model grid, $E R_{\mathrm{ds}}$ shows large variability, ranging from -100 to $+100 \mathrm{~mm}$ w.e. in 2009. In RACMO/27 we find only small values of $\mathrm{ER}_{\mathrm{ds}}$ (not shown; Lenaerts and Van den Broeke, 2012). In order to analyze these differences in more detail, we focus on a horizontal cross section through an area with strong variability in drifting snow erosion $\left(70-72^{\circ} \mathrm{S}\right.$, $148.5^{\circ} \mathrm{E}$; Fig. 6b). Along the transect, the elevation decreases from 2120 to $1550 \mathrm{~m}$ a.s.l. (Fig. 7a). The elevation in RACMO is derived from the $5 \mathrm{~km}$ resolution RADARSAT-1 Antarctic Mapping Project (RAMP) digital elevation model (DEM) (Liu and others, 2001), whereas Figure 7a shows the most recent Antarctic DEM (Bamber and others, 2009) at $1 \mathrm{~km}$ resolution. For unknown reasons, the elevation in the RAMP DEM in this region is significantly offset, by $\sim 60 \mathrm{~m}$, in comparison with the DEM of Bamber and others (2009). From the various elevation datasets, we derived the slope as 


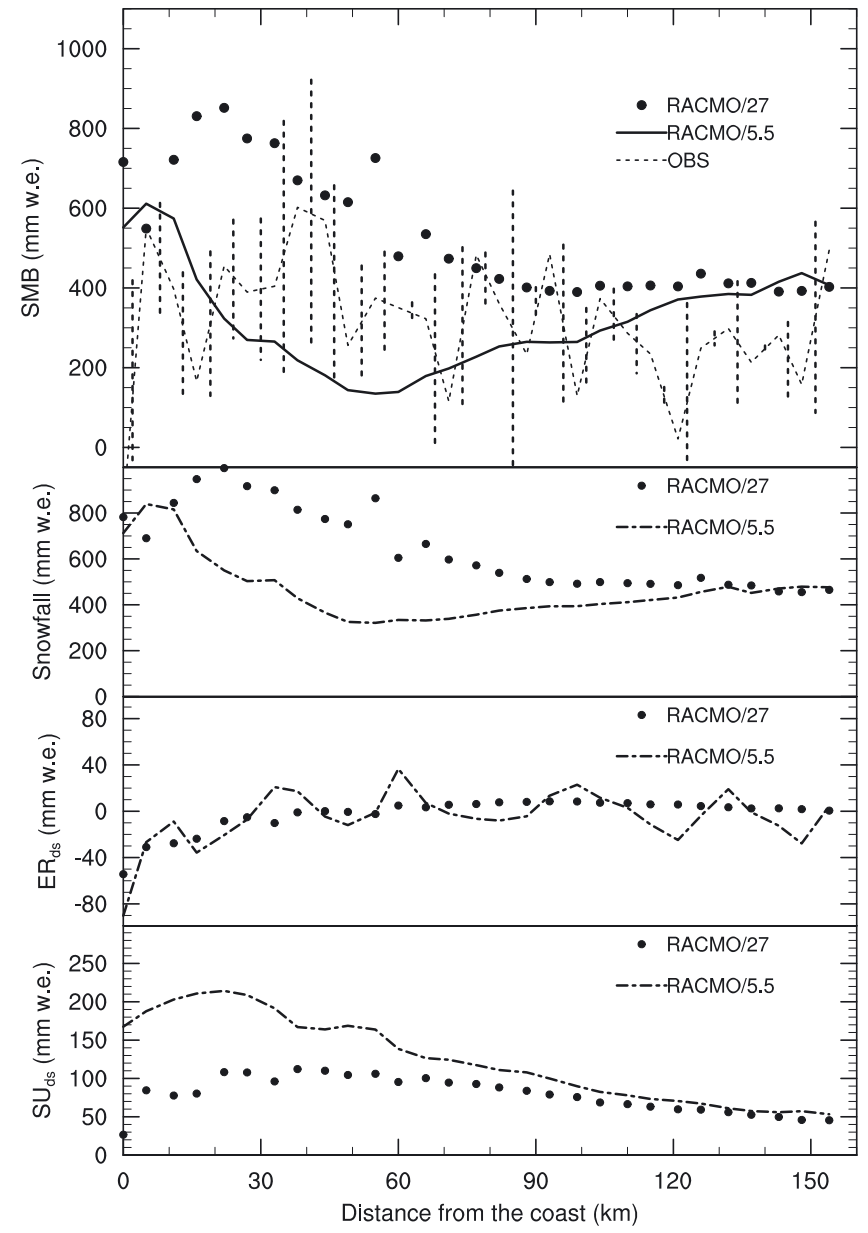

Fig. 8. (a) SMB in 2009 measured by stakes (Agosta and others, 2012) and modeled by RACMO/5.5 (dashed curve) and RACMO/27 (dotted curve). The spatial resolution is $5.5 \mathrm{~km}$, and the modeled data are weighted averages of the four surrounding gridpoints. The vertical dashed bars represent one spatial standard deviation of the observations in both directions. (b) Snowfall, (c) $\mathrm{ER}_{\mathrm{ds}}$ and (d) $\mathrm{SU}_{\mathrm{ds}}$ in 2009, modeled by RACMO/5.5 (dashed curve) and RACMO/27 (dotted curve).

represented in RACMO/27, RACMO5.5 and the $1 \mathrm{~km}$ DEM (Fig. 7b). In all cases, the slope magnitude increases along the transect. The slope in RACMO/5.5 shows larger variability than in $\mathrm{RACMO} / 27$, but has smaller variability than the $1 \mathrm{~km}$ DEM. This implies that important subgrid topographical variability exists that is not resolved by either regional climate model. Although smoothed, RACMO/5.5 captures the spatial variability in slope relatively well.

Along the transect, $10 \mathrm{~m}$ wind speed variations (Fig. 7c) are strongly correlated with the slope, a feature not resolved at $27 \mathrm{~km}$ resolution. This has a profound impact on the spatial variations in drifting snow erosion (Fig. $7 \mathrm{~d}$ ). Whereas $E R_{d s}$ is not significant in $\mathrm{RACMO} / 27, E R_{\mathrm{ds}}$ values of -60 to $+90 \mathrm{~mm}$ w.e. $\mathrm{a}^{-1}$ are found in RACMO/5.5. Generally, $E R_{d s}$ is most negative (positive) just before the strongest wind speed acceleration (deceleration). This illustrates the tight coupling between surface slope, wind speed and drifting snow processes (and their impact on SMB) in katabatic wind regions.

\section{Surface mass balance}

Figure 8 compares the observed and modeled SMB along the stake line, whose location is shown by ' $S$ ' in Figure 9.
RACMO/5.5 performs better than RACMO/27, although SMB remains overestimated near the coast. The strong $S M B$ decrease between 30 and $90 \mathrm{~km}$ from the coast is better represented at $5.5 \mathrm{~km}$ resolution. The mean $\mathrm{SMB}$ bias is greatly reduced from $+222(63 \%)$ to $-12 \mathrm{~mm}$ w.e. $\mathrm{a}^{-1}(3 \%)$, for two reasons: firstly, $\mathrm{SU}_{\mathrm{ds}}$ increases by $\sim 100 \mathrm{~mm}$ w.e., a direct result of higher, more realistic near-surface wind speeds in RACMO/5.5; secondly, snowfall is clearly reduced at $5.5 \mathrm{~km}$ resolution (Fig. 8b), because topography is better represented, inducing more snowfall on the upwind side of the ridges (around $145^{\circ} \mathrm{E}$; Fig. 9) and less snowfall behind these features. It is likely that drifting snow processes are even more important in the coastal regions than modeled by RACMO/5.5. Genthon and others (2007) described the characteristics of the blue-ice area located just off the coast, and concluded that, in ablation years such as 2009, $\mathrm{SU}_{\mathrm{ds}}$ and $E R_{d s}$ remove all accumulated snow, due to the local shape and/or steeper slope of the blue-ice area. This would suggest that $E R_{\mathrm{ds}}$ due to model resolution is still poorly represented by $\mathrm{RACMO} / 5.5$ in this region, since it produces a net convergence of snow in response to weaker winds just before the ice-sheet/ocean interface (Fig. 8).

Lenaerts and others (2012a) present the modeled SMB from $\mathrm{RACMO} / 27$, and found excellent agreement between modeled and observed SMB. However, they found a negative bias in RACMO/27 in northern Victoria Land, which may be attributed to clear-sky precipitation that is not simulated. A similar SMB underestimation is found in RACMO/5.5; compared with the ground-penetrating radar observations of Frezzotti and others (2007) near Talos Dome, the modeled $\mathrm{SMB}$ is $\sim 30 \mathrm{~mm}$ w.e. $\mathrm{a}^{-1}$, whereas the stakes suggest an annual SMB of $\sim 90 \mathrm{~mm}$ w.e. In the near future, an improved precipitation scheme will be included in RACMO that will likely decrease this bias.

Figure 9 compares the $2009 \mathrm{SMB}$ in RACMO/5.5 and $\mathrm{RACMO} / 27$. The large-scale patterns are again similar. Clearly, the spatial variability is larger in RACMO/5.5. Along the Terre Adélie coast we find high SMB values $\left(>1000 \mathrm{~mm}\right.$ w.e. $\mathrm{a}^{-1}$ in $\left.\mathrm{RACMO} / 5.5\right)$ on the east-facing (upwind) topographic ridges, whereas SMB is much lower on the lee sides $\left(<500 \mathrm{~mm}\right.$ w.e. $\mathrm{a}^{-1}$ in $\left.\mathrm{RACMO} / 5.5\right)$. Even larger gradients $(>1500 \mathrm{~mm}$ w.e.) are modeled along the northern coast of Victoria Land (around $72^{\circ} \mathrm{S}, 170^{\circ} \mathrm{E}$ ). This large-scale variability is explained by the strong control of topography on precipitation.

Negative SMB (ablation) is found in large parts of Victoria Land in both simulations. This ablation area is more widespread and patchy in RACMO/5.5, because of the large spatial variations in drifting snow erosion. Regions with similarly alternating patterns of accumulation (SMB > 0) and ablation $(\mathrm{SMB}<0)$ occur where $\mathrm{ER}_{\mathrm{ds}}$ strongly varies (Fig. 6b). These patterns have a typical wavelength of $\sim 10$ $20 \mathrm{~km}$, and are aligned perpendicular to the prevailing wind direction. They represent the steady-state interaction of topography with the atmosphere, as snow converges in front of a dune and is eroded and sublimated away behind it.

Table 1 presents the spatially integrated SMB and its components. Although the SMB difference between RACMO/5.5 and $\mathrm{RACMO} / 27$ is locally large, we find no significant change in domain-integrated SMB; it decreases from $90 \mathrm{Gt}$ to $86 \mathrm{Gt}$ in 2009. $\mathrm{SU}_{\mathrm{ds}}$ is the only $\mathrm{SMB}$ component that significantly increases with increasing horizontal resolution. In $\mathrm{RACMO} / 27$ it is $14 \%$ of the snowfall, and this increases to $21 \%$ of the snowfall at $5.5 \mathrm{~km}$ resolution. In contrast, $\mathrm{SU}_{\mathrm{s}}$ 

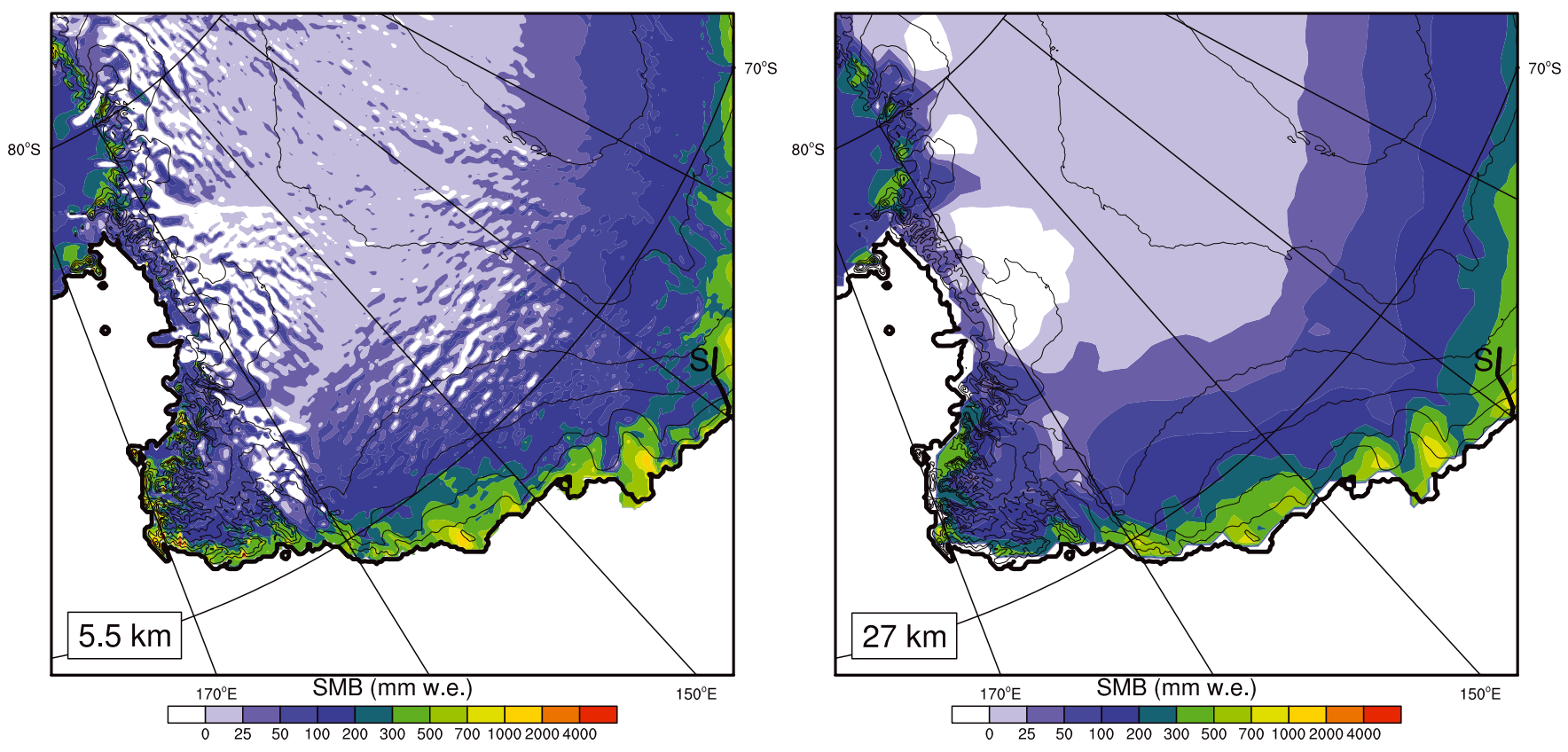

Fig. 9. SMB in 2009 as modeled by RACMO/5.5 (left) and RACMO/27 (right). Note that the $5.5 \mathrm{~km}$ resolution coastline and topography is shown in both plots. The location of the stake line (' $\mathrm{S}$ ') is also shown in both plots.

decreases by $50 \%$ in $\mathrm{RACMO} / 5.5$. The integrated $E R_{\mathrm{ds}}$ remains negligible $(<1 \mathrm{Gt})$ at higher horizontal resolution.

Ablation also occurs in large glacial valleys (Fig. 9), where modeled near-surface wind speeds are high (Fig. 2). In these valleys, drifting snow processes are key components of the $\mathrm{SMB}$. Figure 10 shows the SMB and its components along a transect that approximately follows the center line of Byrd Glacier, whose surface largely consists of blue ice. Figure $10 \mathrm{~b}$ reveals that along the narrow part of the glacial valley, which is $\sim 20 \mathrm{~km}$ wide and $\sim 75 \mathrm{~km}$ long (Stearns and others, 2008; Fig. 10a), drifting snow erosion, $E_{\mathrm{ds}}$, quickly increases from -300 to $+200 \mathrm{~mm}$ w.e., as a result of acceleration of the near-surface flow. In the same area, $\mathrm{SU}_{\mathrm{ds}}$ increases to peak values $>300 \mathrm{~mm}$ w.e. This results in a clearly negative SMB $(<-100 \mathrm{~mm}$ w.e. $)$ along the whole narrow part of the glacial valley. At $\sim 162^{\circ} \mathrm{E}$, where Byrd Glacier terminates into the Ross Ice Shelf, near-surface wind speed decreases and SMB becomes positive again. At $27 \mathrm{~km}$ resolution, these smallscale features are not represented. Stearns (2011) pointed out that earlier estimates (e.g. Van de Berg and others, 2006) overestimate $\mathrm{SMB}$ in the Byrd Glacier catchment. Our results suggest that the inclusion of $\mathrm{ER}_{\mathrm{ds}}$ and $\mathrm{SU}_{\mathrm{ds}}$, along with the higher resolution in RACMO/5.5, leads to a lower, more realistic $\mathrm{SMB}$ for this region.

\section{CONCLUSIONS}

We have described the impact of model resolution on the simulated wind climate, drifting snow and SMB of Terre Adélie and its surroundings. For this purpose, we used the
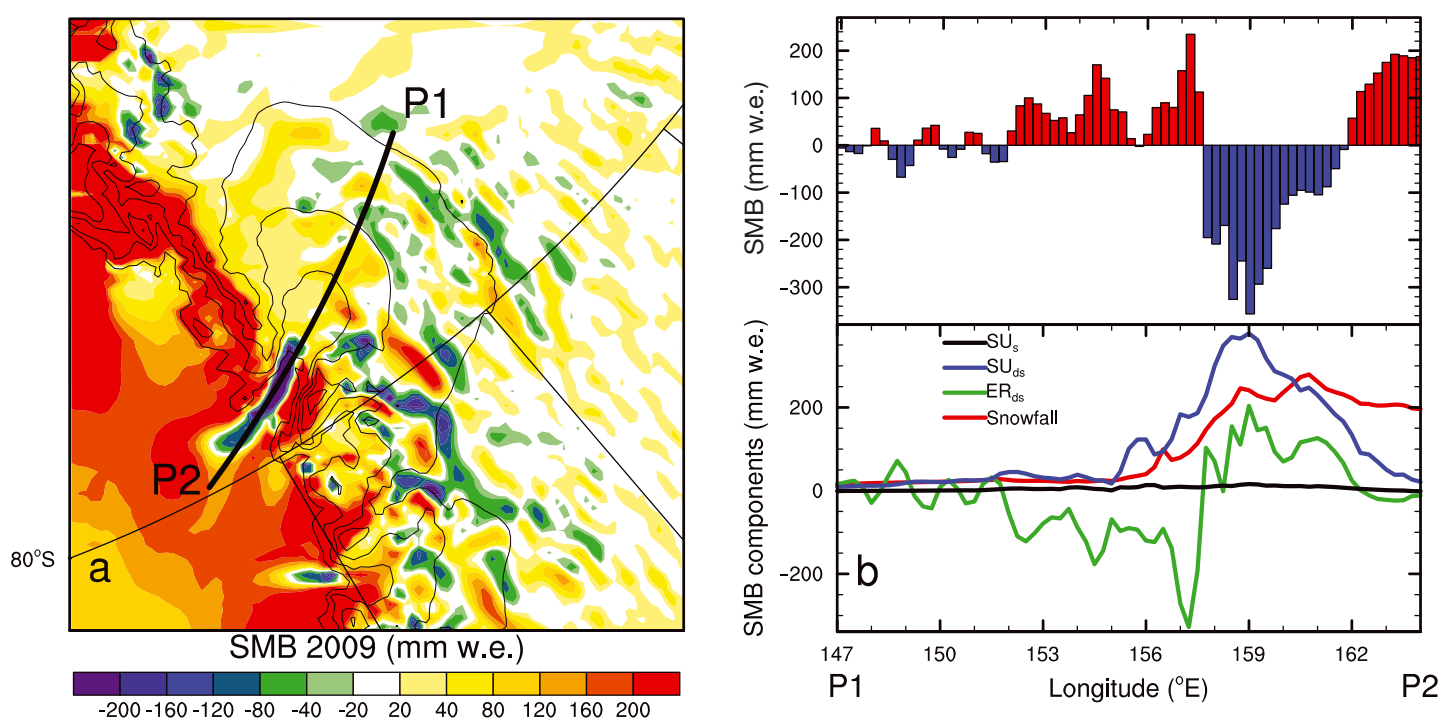

Fig. 10. SMB from RACMO/5.5 along Byrd Glacier. (a) Colors: SMB and location of the transect; black lines: height contours at $500 \mathrm{~m}$ resolution. (b) SMB and its components along the transect. 
Table 1. Domain-integrated values for the year 2009 of snowfall, rainfall, melt, runoff, refreezing, drifting snow sublimation $\left(\mathrm{SU}_{\mathrm{ds}}\right)$, surface sublimation $\left(\mathrm{SU}_{\mathrm{S}}\right)$, total sublimation $\left(\mathrm{SU}_{\mathrm{tot}}=\mathrm{SU}_{\mathrm{ds}}+\mathrm{SU}_{\mathrm{s}}\right)$ and SMB (SMB) for the RACMO/5.5 and RACMO/27 simulations

\begin{tabular}{lcc}
\hline & RACMO/5.5 & RACMO/27 \\
& Gt & Gt \\
\hline Snowfall & 109.6 & 109.4 \\
Rain & 1.6 & 0.5 \\
Melt & 0.9 & 1.1 \\
Runoff & 0 & 0 \\
Refreezing & 2.4 & 1.6 \\
$\mathrm{SU}_{\mathrm{ds}}$ & 22.5 & 15.1 \\
$\mathrm{SU}_{\mathrm{s}}$ & 2.3 & 4.5 \\
$\mathrm{SU}_{\text {tot }}$ & 24.8 & 19.6 \\
$\mathrm{ER}_{\mathrm{ds}}$ & 0.7 & 0.6 \\
$\mathrm{SMB}$ & 85.7 & 89.7 \\
\hline
\end{tabular}

single-year (2009) output of a regional atmospheric climate model at high horizontal resolution $(5.5 \mathrm{~km})$ and compared this with earlier results at $27 \mathrm{~km}$ resolution. Because the topography is much better resolved at $5.5 \mathrm{~km}$, the impact on the simulated climate is significant. Firstly, the near-surface wind speeds are in better agreement with observations in areas with rough topography. We find the strongest annual mean near-surface winds in coastal Terre Adélie $\left(16 \mathrm{~m} \mathrm{~s}^{-1}\right)$ and especially in the narrow glacial valleys in Victoria Land (Byrd, Mulock and David Glaciers; up to $20.5 \mathrm{~m} \mathrm{~s}^{-1}$ ). Horizontal variations in slope magnitude, which are partly resolved at $5.5 \mathrm{~km}$ but not at $27 \mathrm{~km}$, result in horizontal wind speed gradients, which in turn lead to strong variability $(-100$ to $+100 \mathrm{~mm}$ w.e.) of modeled drifting snow erosion, $E R_{d s} . S U_{d s}$ is mainly dependent on wind speed, and is therefore significant in large parts of coastal Terre Adélie (>100 mm w.e.) and along the fast-flowing part of the large East Antarctic glaciers that terminate in the Ross Ice Shelf or Ross Sea.

SMB variability is largely determined by topography, on the large scale (where orographic precipitation is the dominant mechanism), as well as on model gridscale, where we find alternating patterns of ablation $(\mathrm{SMB}<0)$ and accumulation $(S M B>0)$ that are controlled by $E R_{d s}$. Due to the high wind speeds, drifting snow ( $E R_{\mathrm{ds}}$ and $\mathrm{SU}_{\mathrm{ds}}$ ) also leads to ablation in narrow glacier valleys that connect the East Antarctic ice sheet with the Ross Ice Shelf/Sea. We compared modeled SMB with observations along a stake line in Terre Adélie. Although SMB is overestimated at the coast and underestimated further inland, the spatial variability is well represented, and mean SMB bias along the stake line is largely reduced at $5.5 \mathrm{~km}(3 \%)$ compared with $27 \mathrm{~km}(63 \%)$. The spatially integrated SMB is estimated at $86 \mathrm{Gt}$ for 2009 , and is not significantly affected by the horizontal resolution.

\section{ACKNOWLEDGEMENTS}

We thank Thomas Mölg and two anonymous reviewers for valuable comments that considerably improved the paper. This work was supported by funding from the ice2sea programme through the European Union 7th Framework Programme, grant No. 226375. This is Ice2sea contribution No. 091.

\section{REFERENCES}

Agosta C and 6 others (2012) A 40-year accumulation dataset for Adelie Land, Antarctica and its application for model validation. Climate Dyn., 38(1-2), 75-86 (doi: 10.1007/s00382-0111103-4)

Bamber JL, Gomez-Dans JL and Griggs JA (2009) A new 1 km digital elevation model of the Antarctic derived from combined satellite radar and laser data - Part 1: data and methods. Cryosphere, 3(1), 101-111

Bintanja R (1999) On the glaciological, meteorological and climatological significance of Antarctic blue ice areas. Rev. Geophys., 37(3), 337-359 (doi: 10.1029/1999RG900007)

Bromwich DH (1988) Snowfall in high southern latitudes. Rev. Geophys., 26(1), 149-168

Bromwich DH, Parish TR and Zorman CA (1990) The confluence zone of the intense katabatic winds at Terra Nova Bay, Antarctica, as derived from airborne sastrugi surveys and mesoscale numerical modeling. J. Geophys. Res., 95(D5), 5495-5509 (doi: 10.1029/JD095iD05p05495)

Bromwich DH, Rogers AN, Kållberg P, Cullather RI, White JWC and Kreutz KJ (2000) ECMWF analyses and reanalyses depiction of ENSO signal in Antarctic precipitation. J. Climate, 13(8), 1406-1420 (doi: 10.1175/1520-0442(2000) $013<1406$ :EAARDO $>2.0$. CO;2)

Chritin V, Bolognesi R and Gubler H (1999) FlowCapt: a new acoustic sensor to measure snowdrift and wind velocity for avalanche forecasting. Cold Reg. Sci. Technol., 30(1-3), 125-133 (doi: 10.1016/S0165-232X(99)00012-9)

Cierco F-X, Naaim-Bouvet F and Bellot H (2007) Acoustic sensors for snowdrift measurements: how should they be used for research purposes? Cold Reg. Sci. Technol., 49(1), 74-87 (doi: 10.1016/j.coldregions.2007.01.002)

Dee DP and 36 others (2011) The ERA-Interim reanalysis: configuration and performance of the data assimilation system. Q. J. R. Meteorol. Soc., 137(656), 553-597 (doi: 10.1002/qj.828)

Déry SJ and Yau MK (1999) A bulk blowing snow model. Bound.-Layer Meteorol., 93(2), 237-251 (doi: 10.1023/A:1002065615856)

Ettema J and 6 others (2009) Higher surface mass balance of the Greenland ice sheet revealed by high-resolution climate modelling. Geophys. Res. Lett., 36(12), L12501 (doi: 10.1029/ 2009GL038110)

Fahnestock MA, Scambos TA, Shuman CA, Arthern RJ, Winebrenner DP and Kwok R (2000) Snow megadune fields on the East Antarctic Plateau: extreme atmosphere-ice interaction. Geophys. Res. Lett., 27(22), 3719-3722 (doi: 10.1029/ 1999GL011248)

Frezzotti M, Gandolfi S and Urbini S (2002) Snow megadunes in Antarctica: sedimentary structure and genesis. J. Geophys. Res., 107(D18), 4344 (doi: 10.1029/2001JD000673)

Frezzotti M and 12 others (2004) New estimations of precipitation and surface sublimation in East Antarctica from snow accumulation measurements. Climate Dyn., 23(7-8), 803-813 (doi: 10.1007/s00382-004-0462-5)

Frezzotti M, Urbini S, Proposito M, Scarchilli C and Gandolfi S (2007) Spatial and temporal variability of surface mass balance near Talos Dome, East Antarctica. J. Geophys. Res., 112(F2), F02032 (doi: 10.1029/2006JF000638)

Gallée H, Peyaud V and Goodwin I (2005) Simulation of the net snow accumulation along the Wilkes Land transect, Antarctica, with a regional climate model. Ann. Glaciol., 41, 17-22 (doi: 10.3189/172756405781813230)

Genthon C, Lardeux P and Krinner G (2007) The surface accumulation and ablation of a coastal blue-ice area near Cap Prudhomme, Terre Adélie, Antarctica. J. Glaciol., 53(183), 635-645 (doi: 10.3189/002214307784409333)

Genthon C, Krinner G and Castebrunet H (2009) Antarctic precipitation and climate-change predictions: horizontal resolution 
and margin vs plateau issues. Ann. Glaciol., 50(50), 55-60 (doi: 10.3189/172756409787769681)

Kuipers Munneke P, Van den Broeke MR, Lenaerts JTM, Flanner MG, Gardner AS and Van de Berg WJ (2011) A new albedo parameterization for use in climate models over the Antarctic ice sheet. J. Geophys. Res., 116(D5), D05114 (doi: 10.1029/2010JD015113)

Lenaerts JTM and Van den Broeke MR (2012) Modeling drifting snow in Antarctica with a regional climate model: 2. Results. J. Geophys. Res., 117(D5), D05109 (doi: 10.1029/2010JD015419)

Lenaerts JTM, Van den Broeke MR, Van de Berg WJ, Van Meijgaard E and Kuipers Munneke P (2012a) A new, high-resolution surface mass balance map of Antarctica (1979-2010) based on regional atmospheric climate modeling. Geophys. Res. Lett., 39(4), L04501 (doi: 10.1029/2011GL050713)

Lenaerts JTM and 6 others (2012b) Modeling drifting snow in Antarctica with a regional climate model: 1. Methods and model evaluation. J. Geophys. Res., 117(D5), D05108 (doi: 10.1029/2011JD016145)

Liu H, Jezek K, Li B and Zhao Z (2001) Radarsat Antarctic mapping project digital elevation model Version 2. National Snow and Ice Data Center, Boulder, CO. Digital media: http://nsidc.org/data/nsidc-0082.html

Loewe $F(1972)$ The land of storms. Weather, 27(3), 110-121

Mahesh A, Eager R, Campbell JR and Spinhirne JD (2003) Observations of blowing snow at the South Pole. J. Geophys. Res., 108(D22), 4707 (doi: 10.1029/2002JD003327)

Mawson D (1915) The home of the blizzard; being the story of the Australasian Antarctic Expedition 1911-1914. Heinemann, London

Palm SP, Yang Y, Spinhirne JD and Marshak A (2011) Satellite remote sensing of blowing snow properties over Antarctica. J. Geophys. Res., 116(D16), D16123 (doi: 10.1029/2011JD015828)
Parish TR and Bromwich DH (1987) The surface windfield over the Antarctic ice sheets. Nature, 328(6125), 51-54

Sanz Rodrigo J (2011) On Antarctic wind engineering. (PhD thesis, Université Libre de Bruxelles) http://theses.ulb.ac.be/ ETD-db/collection/available/ULBetd-03152011-235458

Scarchilli C, Frezzotti M, Grigioni P, De Silvestri L, Agnoletto L and Dolci S (2010) Extraordinary blowing snow transport events in East Antarctica. Climate Dyn., 34(7-8), 1195-1206 (doi: 10.1007/s00382-009-0601-0)

Stearns LA (2011) Dynamics and mass balance estimates of four large East Antarctic outlet glaciers. Ann. Glaciol., 52(59), 116-126 (doi: 10.3189/172756411799096187)

Stearns LA, Smith BE and Hamilton GS (2008) Increased flow speed on a large East Antarctic outlet glacier caused by subglacial floods. Nature Geosci., 1(12), 827-831 (doi: 10.1038/ngeo356)

Undén P and 26 others (2002) The high resolution limited area model. HIRLAM-5 scientific documentation. Swedish Meteorological and Hydrological Institute, Norrköping (Technical Report)

Van de Berg WJ, Van den Broeke MR, Reijmer $\mathrm{CH}$ and Van Meijgaard E (2006) Reassessment of the Antarctic surface mass balance using calibrated output of a regional atmospheric climate model. J. Geophys. Res., 111(D11), D11104 (doi: 10.1029/ 2005JD006495)

Van den Broeke M, Van de Berg WJ, Van Meijgaard E and Reijmer C (2006) Identification of Antarctic ablation areas using a regional atmospheric climate model. J. Geophys. Res., 111(D18), D18110 (doi: 10.1029/2006JD007127)

Wendler G, Stearns C, Weidner GA and Dargaud G (1997) On the extraordinary katabatic winds of Adélie Land. J. Geophys. Res., 102(D4), 4463-4474 (doi: 10.1029/96JD03438)

White PW (2001) Physical processes (CY23R4), Part IV. European Centre for Medium-Range Weather Forecasts, Reading (Technical Report) 